\title{
Decoding the Growing Relations between Russia and the Taliban : Reasons and Implications
}

\author{
By Zabiullah Farhang ${ }^{1}$
}

\footnotetext{
${ }^{1}$ The author is an International Relations expert based in Kabul, Afghanistan. He appears frequently on panel discussions on Afghanistan's foreign relations at TOLO News. He works at the Nai Foundation-Supporting Open Media in Afghanistan.
} 


\section{Abstract}

The relations between Russia and Taliban are strengthening following one and a half decade of Western presence in Afghanistan. Commenting on this the Russian Special Envoy for Afghanistan and Pakistan Zamir Kabulov said that the establishment of this relation is a "common enemy"- (ISIS) to the Russia and Taliban. This article seeks to find out how the relations between Russia and Taliban have grown and why? Also why does Afghanistan provide an environment for the growth of radical Islamic terrorist groups that tend to be misused by regional players in Afghanistan? The hypothesis is that the principal factor is cultural in nature. However, there would more reasons such as external financial, military and political support., But these factors only become operational and effective in a favorable context.

\section{Key Words: Russia- Taliban, Radical groups, ISIS, Terrorism, Drugs Transit.}

\section{Conferences for Afghanistan Peace negotiation}

Russia hosted the third round of the Afghan Peace Conference in Moscow on $13^{\text {th }}$ April, 2017. It tried to make this conference more inclusive and hence different from the previous ones. Russia invited Iran, Pakistan, China, India, the five Central Asian Republics and also the US. But Washington chose not to participate in this conference and expressed concern on relations between Moscow, Iran, Pakistan with the Taliban. The Leader of NATO's Operation Resolute Support mission to Afghanistan, General Nicholson remarked: "So, Russia has overtly lent legitimacy to the Taliban".

Taliban were supported by Pakistan in the last sixteen years. There is a claim that ISI (InterServices Intelligence) had started to support the Taliban from the 1990's and it's continuing up-till now. The support consists of radicalization through madrassas as well as financial help and safe sanctuary. But now in addition to Islamabad, Russia, China and Iran too have found common cause with the Taliban (Samuel Ramani, December 29, 2016). 
Some Afghan experts and military analysts believe that Moscow strengthened its relations with Taliban in last two years. Taliban's affiliation to the Russia was unclear before 2014, but during the last two years (2014 to 2016) Russia's equations with the Taliban have shifted dramatically. Former chief of police in Kunduz province Qasim Jangalbagh believes that Mullah Abdulsalam the Taliban governor for Kunduz province had participated in the Russia, China and Pakistan Tripartite Conference in Tajikistan, which was held on $26^{\text {th }}$ Dec 2016. (Shahryar, 2016:1). He asserts that "Taliban is a terrorist group, if Russia is going to have relations with this terrorist group, it gives legitimation to a terrorist group that killing every day Afghans including: our Police, Armies, elders, young, men, women and children". Thus implying that Russia is supporting the enemies of Afghanistan and giving legitimacy to the Taliban's. This is an insult to the blood of our people who are being killed every day by the Taliban.. Terrorism is not merely a challenge for Afghanistan but it is an international threat against all people in the world including Russia, Pakistan, Iran and other their supporters. Russia through its current actions is contributing to rebuilding enmity between Afghanistan and Russia, which could be disadvantage Moscow, and Kabul (Hamid, Shalizi. Josh, Smith dec-08-2016).

Reports indicate that relations between Russia and the Taliban began to grow in 2007, when narcotics production increased especially in southern provinces of Afghanistan leading to increased trafficking to Russia and onwards to Europe via the Central Asian Republics. Officials in Moscow are believed to have established relations with the Taliban leaders to combat narcotics problem. But Taliban couldn't or didn't want to carry out whatever Russia had wanted off them. (Wahid Muzhda, November 22, 2013).

The second indication of relations between Russia and Taliban changing was seen on $08^{\text {th }}$ April,, 2013, when the Taliban captured a Russian pilot in Logar Province in central area of Afghanistan. After few days of the matter coming to light, Russian diplomats and some of the Taliban delegates met up in the United Arab Emirates. A few months later, the Russian pilot was released. These events raised a lot of questions among the political circles in Afghanistan (Wahid Muzhda, November 22, 2013). (Hamid, Shalizi. Josh, Smith dec-08-2016).

In 2014, when the International troops began withdrawing from Afghanistan, the Russian government was worried regarding the security fallouts. It went on to warn the West in 
general and US in particular that given the weakness of the Afghan government the country might once again become again a safe haven for the international terrorist networks. Thus implying a potential failure of the US led international mission counter international terrorism in Afghanistan.

In 2014, reports emerged of ISIS establishing itself in Nangarhar province in eastern Afghanistan. At the beginning, majority of the Afghan populace and politicians didn't believe these reports. However as the ISIS staged several terrorist attacks in Afghanistan people were increasingly convinced that ISIS was a new reality in the country besides the Taliban and other suspected militant groups. The group had outraged locals in Nangarhar as graphic videos emerged of their brutal tactics against enemy combatants as well as civilians who did not toe their line.

The question is that why do radical movements claiming to be anchored in Islam and propagating violent jihad in the name of Islam arise in Afghanistan? And why do some regional players support these movements? To answer the first question, Afghanistan provides the social and cultural milieu for violent extremist movements to take root. Most of the people in this country are illiterate and are vulnerable prey for the radical Islamists. It makes many people believe in the idea of their duty to carry out jihad against non-Muslims. The Taliban too employ a similar discourse claiming that they are true Muslims fighting to protect Islam, against foreign transgressions. The ISIS too claims to be fighting for Islam, albeit globally.

These radical movements in the south and central Asia have ideological compatriots across geo-political borders. Russia therefore believes that if they support the Taliban they would be protected from the Taliban's temptation to expand their influence in Russia's periphery i.e. in Central Asia. Following the appearance of ISIS in Afghanistan, Russians claim that they and the Taliban have "Common Enemy" which is ISIS.. Moscow believes if ISIS spreads in Afghanistan they will penetrate Central Asia probably through north of Afghanistan,

Thus, Russia has developed an appetite to strengthens its relations with the Taliban. However, Afghan government officials have been extremely disapproving of these developments, stating that: 
"Afghanistan wants relation state to state, if any country is contacting with any terrorist groups like Taliban it means that they give legitimation to them, whereas Taliban killing our people every day. We want good relation with all states in the region and the world, and we hope that other states should have relations the same with us". (Matthew Gault, April 15, 2017).

\section{Conclusion}

Thus, Afghanistan's cultural and social milieu is an important factor along with other consideration highlighted in providing fertile ground for the rise of terrorism and fundamentalism. The Taliban phenomenon has grown out of this milieu, supported financially and physically by regional powers. It's clear that Russia, Pakistan and Iran have supportive relations with them, the relations between Russia and Taliban is a reality now. There is no doubt that Russia is providing Weapons to Taliban (Barney Henderson, 24 APRIL 2017). But the main problem is cultural issues that is endorse their terrorist activities in Afghanistan.

\section{References:}

Aljazeera. US officials in Afghanistan suggest Russia arms Taliban Top US military officials allude to increasing concerns over Moscow's role in Afghanistan. Retrieved http://www.aljazeera.com/news/2017/04/officials-afghanistan-suggest-russia-arms-taliban170424204006251.html.

Barney, Henderson. (April 24, 2017). US general in Afghanistan says there is no doubt Russia is providing weapons to Taliban. The Telegraph. Retrieved http://www.telegraph.co.uk/news/2017/04/24/usgeneral-afghanistan-says-no-doubt-russiaproviding-weapons/.

Hamid, Shalizi. Josh, Smith. (December 08, 2016). Ties between Russia and the Taliban worry Afghan, U.S. officials. REUTERS. Retrieved 01-03-2017. http://www.reuters.com/article/us-afghanistan-russia-idUSKBN13W2XJ.

Exclusive interview with Russian diplomat Zamir Kabulov Vladimir Putin's envoy to Afghanistan speaks about the country's past, present, and future in wide-ranging interview. 
Retrieved via http://aa.com.tr/en/asia-pacific/exclusive-interview-with-russian-diplomatzamir-kabulov/717573.

Interview with Wahid Muzhda, Former diplomat in the Ministry of Foreign Affairs, Kabul, August 2016.

Najib, Sharifi. (Feb 26, 2017). Russia's new game in Afghanistan Vladimir Putin's posturing towards Afghanistan has opened a new chapter in the great game in the heart of Asia. Retrieved http://www.aljazeera.com/indepth/opinion/2017/02/russia-game-afghanistan170223095212195.html.

Ramani, Samuel (December 29, 2016). Russia and the Taliban: A Closer Look. Why is Putin reaching out to the Afghan Taliban? The Diplomat. Retrieved 04-05-2017 from http://thediplomat.com/2016/12/russia-and-the-taliban-a-closer-look/.

Zia, Shahryar (26 Feb, 2016). Taliban and Russia relation: is there other big game? bbc. Retrieved http://www.bbc.com/persian/afghanistan-38438820. 